\title{
Konflik Masyarakat Lokal Dengan Pengusaha Pariwisata Terkait Akses Pura Batu Mejan Dan Setra Di Desa Canggu, Kabupaten Badung
}

I Gede Fanny Putra Jaya a, 1, I Gusti Agung Oka Mahagangga a, 2

1fannyptr20@gmail.com,2okamahagangga@unud.ac.id

a Program Studi S1 Destinasi Pariwisata, Fakultas Pariwisata,Universitas Udayana, Jl. Dr. R. Goris, Denpasar, Bali 80232 Indonesia

\begin{abstract}
The growth of accomodation number in Canggu Village is very significant and happen on the seashore. Canggu village is a strategic place for investors to invest today. One of accomodation that has been built by investors in this village is Canggu Intercontinental Hotel. The building process of this hotel experienced many problems caused by violation of agreement between investors and local people. Thus, this research aims to determine the conflicts between local people of Canggu village and tourism investors.

This research conducted in Canggu village, Kuta Utara subdistrict, Badung regency. The type of data used is qualitative data. The data source used are primary and secondary data. The data collecting technique used are indepth interview, observation, and literature study. The method used to determine informants is purposive sampling technique, and the informants are chief of Banjar Canggu and head of orderliness and peacefully section of Kuta Utara subdistrict. This research is limited by concept of agreement, concept of local people, and theory of conflict.

The result of this research is that the conflicts between local people and tourism investors about access of Batu Mejan and Canggu cemetery in Canggu village, Badung regency are manifest and latent conflict. The manifest conflict is in the form of road blockade to Canggu Intercontinental Hotel construction which done by local people. The latent conflict is in the form of local issues that emerged among local people which can lead them to do physical actions or manifest conflicts with the investors. Those conflicts are proofs of disagreement between local people and investors regarding to the access of local cemetery and Batu Mejan Temple in Canggu village.
\end{abstract}

\section{Keywords : Conflicts, Local People, Tourism Investors, Canggu Village.}

\section{PENDAHULUAN}

Pariwisata merupakan industri dunia yang mampu meningkatkan devisa suatu negara, khususnya Indonesia. Pada tahun 2015, pariwisata menempati urutan ke-4 perolehan devisa Indonesia dengan jumlah nilai US\$ 12,5 juta setelah minyak dan gas bumi, batu bara, dan minyak kelapa sawit (Sumber : Pitana, 2016). Keindahan alam serta keragaman budaya menjadi faktor majunya sektor pariwisata di Indonesia dan Bali pada khususnya. Sebagai destinasi utama bagi wisatawan baik nusantara maupun mancanegara, angka kunjungan wisatawan di Bali cenderung meningkat setiap tahunnya.

Pada tahun 2014, data jumlah wisatawan mancanegara ke Bali adalah 3.766.638 orang sedangkan tahun 2015 meningkat sebesar $6,24 \%$ menjadi 4.001 .835 orang. Sedangkan data jumlah wisatawan nusantara ke Bali tahun 2014 adalah 6.394.307 orang yang mana meningkat sebesar 11,77\% pada tahun 2015 menjadi 7.147.100 orang (Sumber : Pitana, 2016). Hal ini membuat para investor memandang bahwa Bali tidak hanya sebagai tempat berlibur semata melainkan juga menjadi tambang emas untuk berinvestasi terutama dalam bidang akomodasi seperti hotel, resort, villa, homestay, dan penginapan.

Kawasan Bali selatan kini menjadi sasaran pembangunan akomodasi yang memiliki view pantai dengan nilai jual yang sangat tinggi serta letaknya yang strategis. Peluang ini kerap menjadi alasan bagi pihak investor untuk berinvestasi menggunakan segala cara agar berhasil dalam berbisnis akomodasi. Hal ini juga sering menimbulkan konflik khususnya antara masyarakat lokal dengan pihak investor. 
Salah satu daerah di Bali selatan yang mengalami pesatnya pembangunan akomodasi adalah Desa Canggu, Kecamatan Kuta Utara, Kabupaten Badung, Bali. Pembangunan akomodasi di sepanjang pesisir pantai ataupun di pinggir jalan menuju pantai sangat pesat. Potensi wisata yang dimiliki oleh Desa Canggu membuat investor beranggapan bahwa Canggu merupakan kawasan strategis untuk berinvestasi. Penduduk Desa Canggu yang semula adalah nelayan dan petani, mulai bergeser ke sektor pariwisata. Di sisi lain, alih fungsi lahan menunjukkan perubahan signifikan dari lahan sawah menjadi pemukiman teruntuk akomodasi wisata. Perubahan ini secara spasial dan sosial akan memberi pengaruh atau berdampak secara positif maupun negatif.

Saat ini telah terdapat proyek pembangunan hotel di jalan Munduk Catu, Desa Canggu yang menimbulkan pro dan kontra antara masyarakat lokal dengan pihak investor. Proyek tersebut adalah pembangunan Hotel Canggu Intercontinental yang tidak sesuai dengan kesepakatan awal antara masyarakat lokal sehingga rentan terjadi konflik. Melihat fenomena tersebut, penelitian ini penting dilakukan untuk mengetahui konflik dan upaya penyelesaian yang terjadi antara masyarakat lokal dengan pihak investor.

\section{TINJAUAN PUSTAKA}

Ada dua telaah hasil penelitian sebelumnya yang berkaitan dengan penelitian ini. Telaah hasil penelitian sebelumnya yang pertama bersumber dari sebuah jurnal yang terkait dengan fokus penelitian yakni dilakukan oleh Kusuma (2012). Persamaan antara penelitian tersebut dengan penelitian yang dilakukan yakni keduanya membahas tentang konflik antara masyarakat lokal dengan pengusaha. Sedangkan perbedaannya adalah bahwa penelitian tersebut dilakukan di Pantai Mertasari Sanur sedangkan penelitian ini dilakukan di Desa Canggu, Kabupaten Badung.
Telaah hasil penelitian sebelumya yang kedua juga bersumber dari sebuah jurnal yang terkait dengan lokasi penelitian yakni dilakukan oleh Permilasari (2014). Penelitian tersebut memiliki persamaan dengan penelitian ini yakni keduanya dilakukan di Desa Canggu, Kabupaten Badung. Sedangkan perbedaannya adalah penelitian tersebut membahas tentang bentuk pengelolaan Pantai Batu Bolong sebagai daya tarik wisata surfing sedangkan penelitian ini membahas tentang konflik masyarakat lokal dengan pengusaha pariwisata.

Konsep yang digunakan dalam penelitian ini adalah konsep kesepakatan yang bersumber dari Pasal 1320 KUH Perdata, konsep masyarakat lokal (Koentjaraningrat, 2009), dan konsep konflik sosial (Bebbington, 1997 dalam Dharmawan, 2006). Dengan mengikuti konsep konflik sosial berperspektifkan ruang-kekuasaan dari Bebbington (1997), maka konflik sosial antar "pemangku kekuasaan" dapat berlangsung dalam tiga bentuk, yaitu:

1) Warga masyarakat sipil atau kolektivitas sosial berhadap-hadapan melawan negara dan sebaliknya. Dalam hal konflik sosial dapat terjadi dalam bentuk protes warga masyarakat atas kebijakan publik yang diambil oleh negara/pemerintah yang dianggap tidak adil dan merugikan masyarakat secara umum. Perlawanan asosiasi pedagang kaki-lima di Jakarta melawan penggusuran oleh Pemerintah DKI Jaya adalah contoh klasik yang terus kontemporer.

2) Konflik sosial yang berlangsung antara warga masyarakat atau kolektivitas sosial melawan swasta dan sebaliknya. Contoh klasik dalam hal ini adalah "perseteruan berdarah" yang terus berlangsung (bahkan hingga kini) antara komunitas lokal melawan perusahaan pertambangan multinasional di Papua. Kasus serupa juga ditemui dalam "Tragedi Pencemaran Teluk Buyat" yang memperhadapkan warga lokal yang 
menderita kesakitan akibat pencemaran air terus-menerus dari limbah tailing aktivitas penambangan emas oleh perusahaan swasta asing di Sulawesi Utara di awal dekade $2000 \mathrm{an}$

3) Konflik sosial yang berlangsung antara swasta berhadap-hadapan melawan negara dan sebaliknya. Berbagai tindakan yang diambil oleh Pemerintah/Negara dalam mengawal jalannya sebuah kebijakan, biasanya memakan biaya sosial berupa konflik tipe ini secara tidak terelakkan.

Dinamika konflik sosial antar-ruang kekuasaan akan berlangsung makin kompleks, manakala unsur-unsur pembentuk sebuah ruang kekuasaan tidak merepresentasikan struktur sosial dengan atribut/identitas sosial yang homogen. Di ruang kekuasaan negara, termuat sejumlah konflik sosial internal baik yang bersifat laten (terselubung-terpendam) maupun manifest (mewujud-nyata).

Konsep kesepakatan digunakan untuk mengidentifikasi bagaimana pihak masyarakat lokal dan pihak investor menyikapi sebuah kesepakatan yang terjadi sebelum terjadinya konflik. Konsep masyarakat lokal digunakan untuk mengidentifikasi interaksi antara masyarakat lokal, adat istiadat, serta rasa identitas yang kuat dan mengikat seluruh masyarakat. Konsep konflik digunakan untuk mengklasifikasikan bentuk konflik yang terbagi atas konflik laten dan konflik manifest.

\section{METODE}

Data primer yang dimaksud meliputi observasi kondisi proyek pembangunan Hotel Canggu Intercontinental serta wawancara mendalam dengan Kepala Desa Canggu, Bendesa Desa Canggu, Kelian Banjar Desa Canggu, dan Camat di Kuta Utara. Sedangkan data sekunder yang dimaksud meliputi data yang dikumpulkan dari internet seperti jurnal dan berita terkait konflik yang terjadi di Desa Canggu.
Teknik pengumpulan data yang digunakan meliputi wawancara mendalam (Sugiyono, 2014), observasi (Kusmayadi, 2000), dan studi kepustakaan (Nazir, 2003). Teknik penentuan informan menggunakan Purposive Sampling (Bungin, 2007). Pihak informan yang diwawancara diantaranya Kepala Desa Canggu, Bendesa Desa Canggu, Kelian Banjar Desa Canggu, dan Camat di Kuta Utara. Observasi dilakukan dengan cara mengamati situasi dan kondisi proyek pembangunan Hotel Canggu Intercontinental. Sedangkan studi kepustakaan dilakukan dengan cara mengumpulkan data dari internet seperti jurnal dan berita terkait konflik yang terjadi di Desa Canggu.

Teknik analisis data menggunakan analisis data kualitatif yang dikemukakan oleh Miles dan Huberman dalam Sugiyono (2014). Aktivitas dalam analisis data kualitatif dilakukan secara interaktif dan berlangsung terus menerus sampai tuntas, hingga datanya jenuh. Tahapan analisis tersebut meliputi reduksi data, penyajian data, serta verifikasi atau penarikan kesimpulan.

\section{HASIL DAN PEMBAHASAN}

\section{Gambaran Umum Desa Canggu}

Desa Canggu terletak di Kecamatan Kuta Utara, Kabupaten Badung, Bali. Desa ini berbatasan di bagian utara berbatasan dengan Desa Dalung, di bagian timur berbatasan dengan Tibubeneng, di bagian selatan berbatasan dengan Samudra Indonesia, dan di bagian barat berbatasan dengan Pererenan, Mengwi. Luas keseluruhan Desa Canggu adalah 371,5 Ha.

Desa Canggu terkenal akan pantainya yakni pantai Canggu. Pantai ini menjadi salah satu daya tarik wisata yang kini berkembang pesat. Wisatawan yang datang berkunjung umumnya bertujuan untuk melakukan aktivitas surfing ataupun berjemur di pinggir pantai. Kondisi yang lebih sepi dibandingkan dengan 
Kuta disukai oleh para wisatawan. Ombak di pantai Canggu juga tidak jauh berbeda seperti pantai Kuta sehingga sangat baik digunakan untuk berselancar.

Ramainya wisatawan yang berkunjung ke pantai Canggu membuat pembangunan akan fasilitas juga semakin meningkat. Homestay, villa, hotel, dan restoran sudah semakin menjamur di areal sekitar pantai Canggu mengingat wilayah Seminyak, Legian, dan Kuta semakin sempit dan sesak. Pariwisata pantai di Badung kini mulai merambah menuju utara dengan karakter pantai yang tak jauh berbeda sehingga juga mendorong para investor untuk melirik wilayah baru.

Adanya pembangunan berskala besar tidak jarang menimbulkan pro dan kontra. Situasi dan kondisi ini muncul akibat salah satu pihak yang mengorbankan kepentingan pihak lainnya. Jika tidak ditemukan titik penyelesaian maka sudah pasti hal tersebut dianggap sebagai konflik. Hal demikian juga terjadi di Desa Canggu, dimana terdapat konflik antara masyarakat Desa Canggu dengan pihak Hotel Canggu Intercontinental atau dalam konteks ini adalah investor. Ketidaksediaan investor dalam memenuhi kesepakatan antara kedua belah pihak menjadi akar timbulnya konflik dan membuat masyarakat geram.

\section{Konflik antara Masyarakat Desa Canggu dengan Pengusaha Pariwisata}

Jalan Munduk Catu merupakan jalan umum yang menjadi akses masyarakat menuju setra (kuburan) adat Canggu dan Pura Batu Mejan. Di bagian ujung timur dari jalan Munduk Catu merupakan area setra dan di sebelah barat sekitar 400 meter dari jalan tersebut terdapat pura umum yaitu Pura Batu Mejan. Diantara Pura Batu Mejan dengan jalan Munduk Catu dipisahkan dengan lahan kosong dan loloan, yang berada di sebelah barat dan timur dari jalan. Lahan kosong tersebut memiliki luas
419,2 are yang merupakan lahan kepemilikan dari 11 orang warga Desa Adat Canggu.

Sejak tahun 2012, lahan kosong yang dulunya tidak produktif itu dibeli oleh investor dan di alih fungsikan menjadi hotel. Keseluruhan lahan yang dimaksud meliputi lahan kosong di bagian barat dan timur jalan Munduk Catu sehingga saat ini sepenuhnya dimiliki oleh investor.

Sebelum pengerjaan proyek dimulai, ada beberapa kesepakatan yang dibuat antara masyarakat lokal Desa Canggu dengan pihak investor. Kesepakatan tersebut tertuang dalam Berita acara kesepakatan antara masyarakat Desa Canggu dengan pihak Hotel Canggu Intercontinental yang dibuat pada tanggal 7 Oktober 2012 sebanyak 7 (tujuh) poin kesepakatan sebagai berikut:

1. Pihak pertama (Surjantoro Siswanton/ PT. Canggu Internasional) bersedia membangun jalan Munduk Catu sepanjang +/-600 dengan konstruksi aspal hot mix sepanjang 600 meter selebar 5 meter. Rencana Anggaran Biaya (RAB) sebesar Rp. 1.072.000.000,00 (Satu Miliar Tujuh Puluh Dua Juta Rupiah) ditanggung oleh Pihak Pertama.

2. Lebar badan jalan 5 meter panjang 600 meter dengan kontruksi subbase lime stone dan senderan pasang batu di kedua sisi sampingnya. Pembuatan saluran drainase got akan dikerjakan oleh masing-masing pemilik tanah membangun di lokasi tanah miliknya.

3. Pihak Kedua (Kepala Desa Canggu, Kelian Banjar Adat Canggu, Kelian Dusun Canggu dan Perwakilan masyarakat) berhak memungut biaya/uang pemeliharaan jalan bagi pemilik tanah di sepanjang jalan Munduk Catu apabila pemilik tanah akan mulai mendirikan bangunan. Uang hasil pungutan/sumbangan akan dipakai untuk pemeliharaan jalan bersama-sama bagi pengguna jalan. Pihak Kedua tidak akan memungut biaya apapun juga yang 
berkaitan dengan pemakaian jalan kepada Pihak Pertama selamanya.

4. Masa berlaku kesepakatan ini berlaku surat kepada manajemen dan pemilik hotel berikutnya serta siapapun pengganti pejabat Kepala Desa Canggu, Kelian Banjar Adat Canggu dan Kelian Dinas Banjar Canggu.

5. Apabila masyarakat membutuhkan jalan untuk melewati/menggunakan jalan landscape di depan lokasi hotel yang berdekatan dengan pantai dengan tujuan ke Pura dalam acara adat maka Pihak Kedua selaku kuasa dari masyarakat berkewajiban memberikan surat permohonan secara tertulis selambat-lambatnya 7 hari kerja sebelum tanggal penggunaan fasilitas tersebut kepada manajemen hotel. Berlaku juga untuk jalan setapak sebelah loloan.

6. Bilamana kesepakatan ini telah ditandatangani Pihak Pertama berhak segera membangun jalan tersebut tanpa keberatan/claim dari pihak manapun juga, maka Pihak Kedua wajib menyelesaikan keberatan/claim tersebut tanpa mengganggu proses pekerjaan dilapangan. Pihak Kedua bertanggung jawab atas kerugian Pihak Pertama apabila terjadi penghentian pekerjaan yang disebabkan oleh pihak pihak lainnya.

7. Tindak lanjut materi kesepakatan ini akan dibuat BERITA ACARA KESEPAKATAN Warga Canggu dengan Hotel Canggu Intercontinental yang disahkan oleh Notaris.

Kesepakatan tersebut menjadi awal pengerjaan proyek oleh PT. Canggu Intercontinental sebagai pelaksana proyek. Proyek pembangunan hotel ini merupakan proyek terbesar di daerah Canggu dengan luas 419,20 are yang dipisahkan oleh jalan Munduk Catu. Bagian barat jalan memiliki luas 295,00 are dan di bagian sisi barat berbatasan dengan loloan. Kemudian lahan di bagian timur dari jalan Munduk Catu memiliki luas 124,20 are.

PT. Canggu Intercontinental mengantongi tiga jenis izin yakni izin prinsip nomor 556.5/343/Diparda tertanggal 24 Januari 2012, UKL/UPL nomor 660.1/110/LH tertanggal 13 Februari 2012, serta UKL/UPL Tanggul (Pengaman Pantai) nomor 660.1/773/LH tertanggal 3 November 2011. Adanya ketiga izin tersebut membuat pihak investor mulai mengerjakan proyek Hotel Canggu Intercontinental.

Selama dua tahun proyek tersebut dikerjakan terlihat adanya tembok yang mengelilingi lokasi proyek seperti mencaplok sempadan pantai. Di bagian selatan proyek yang berdekatan langsung dengan pantai dibangun LGater setinggi 4 meter dan juga pembangunan underpass untuk menghubungkan kedua lahan yang dibatasi oleh jalan Munduk Catu. Melihat kondisi seperti ini, Banjar Canggu mengadakan rapat yang dihadiri oleh pihak investor yakni owner Canggu Intercontinental pada hari Sabtu, 25 April 2015. Rapat ini diadakan atas dasar protes dari warga karena pembangunan proyek tidak sesuai dengan kesepakatan sebelum proyek dikerjakan. Penyimpangan kesepakatan yang dimaksud antara lain :

1. Pembuatan under pass yang tentunya tidak ada dalam kesepakatan awal.

2. Ketinggian LGater melebihi jalan setapak yang memang sudah ada sebelumnya sehingga permintaan masyarakat Canggu kepada pihak investor untuk menyediakan jalan setapak untuk menghubungkan antara Pura Batu Mejan dengan Setra Desa Adat Canggu tidak mungkin terealisasi karena ketinggian LGater yang terlalu tinggi.

3. Tembok hotel mencaplok sempadan pantai.

4. Tidak disediakannya selokan di kanan maupun di kiri jalan Munduk Catu.

Atas penyimpangan tersebut, pihak masyarakat Banjar Adat Canggu mengajukan 5 poin kesepakatan kepada pihak Hotel Canggu Intercontinental diantaranya :

1. Mengurangi ketinggian LGater karena terlalu tinggi. Benturan ombak yang terlalu keras 
pada LGater setra adat menjadi sasaran abrasi.

2. Pihak investor diwajibkan merelakan tanahnya yang berada di pinggir pantai untuk membuat jalan setapak sebagai akses masyarakat menuju Pura Batu Mejan serta dan untuk menghindari air laut pasang masyarakat supaya bisa melewati jalan landscape (jalan setapak pinggir pantai). Hal ini diharapkan agar masyarakat tidak perlu meminta ijin lewat kepada manajemen hotel.

3. Permintaan dari masyarakat, tanah kepemilikannya supaya diukur kembali dengan sertifikat pemilik pertama agar jelas batasan sempadan pantai dan batas sempadan sungai.

4. Jalan Munduk Catu yang didanai oleh investor untuk mengaspal supaya dikembalikan seperti semula, selokan di kiri dan kanan jalan supaya ada dan tembus ke pantai. Jalan Munduk Catu agar diserahkan kepada pemerintah/ PEMDA Kabupaten Badung agar diaspal. Jalan Munduk Catu agar tidak menjadi bahan perundingan dan dicabut dari kesepakatan.

5. Gorong-gorong yang menyebrang jalan supaya di bongkar secepatnya dan tanahnya diratakan seperti semula.

Namun dari lima tuntutan tersebut terlihat bahwa kesepakatan tidak sesuai dengan apa yang dikehendaki oleh pihak pertama (masyarakat) dengan pihak kedua (Hotel Canggu Intercontinental). Ketidaksesuaian ini dikarenakan tujuan dari masing-masing pihak tidak sama dan tidak adanya timbal balik. Kelian Banjar Adat Canggu, I Wayan Mustara menerangkan bahwa pihak investor telah menyanggupi dalam memenuhi tuntutan masyarakat. Tetapi kenyataan di lapangan menyatakan bahwa pihak investor melanggar kesepakatan tersebut. Kondisi ini menimbulkan anggapan dari pihak masyarakat bahwa pihak investor telah berbohong. Hal tersebut juga diperkuat dengan tidak adanya pengerjaan atau konstruksi atas akses jalan yang disepakati.
Adapun kutipan hasil wawancara dengan Kelian Banjar Adat Canggu sebagai berikut :

"Pihak investor kita wajibkan untuk membuat jalan itu dan pihak investor sanggup dengan memberikan landscape 2,4 meter pada saat itu, dan ternyata di area itu temboknya tidak terwujud landscape itu, karena tidak ada terwujud itulah yang dipermasalahkan dan seperti pihak investor berbohong" (Hasil wawancara dengan I Wayan Mustara, 23 Maret 2016).

Senada dengan KASITRANTIB Kecamatan Kuta Utara, I Gusti Ngurah Oka juga membenarkan bahwa pihak investor yang berkewajiban dalam penyediaan lahan jalan selebar 2,4 meter sesuai kesepakatan tidak dilakukan. Beliau menuturkan bahwa :

"Memang benar terjadi kesepakatan awal terkait akses jalan setapak dari Setra Canggu menuju ke Pura Batu Mejan, hal ini disepakati oleh masyarakat lokal dengan pihak Hotel Canggu Intercontinental tetapi kesepakatan ini tidak dilakukan dan jalan pun tidak disediakan oleh pihak investor, sehingga hal tersebutlah yang dianggap bohong oleh masyarakat lokal" (Hasil wawancara dengan I Gusti Ngurah Oka, S.H., 23 Mei 2016).

Kedua pernyataan tersebut menjelaskan bahwa dengan menyetujui ajuan kesepakatan dari pihak masyarakat, secara langsung pihak investor memiliki kewajiban untuk menyediakan jalan dengan lebar 2,4 meter sesuai kesepakatan yang telah dibuat oleh kedua belah pihak. Hal tersebut juga tentu wajib dilakukan karena adanya kesanggupan dari pihak investor. Namun yang terjadi di lapangan berbeda. Pihak investor tidak menunaikan kewajiban tersebut. Pembangunan akses yang disetujui oleh kedua belah pihak tidak berwujud sedikitpun. Kesenjangan antara 
masyarakat lokal dengan pihak investor tidak dapat dihindarkan sehingga menimbulkan adanya konflik. Berdasarkan hasil penelitian maka diperoleh fenomena konflik seperti dijelaskan di bawah :

\section{a. Konflik Laten antara Masyarakat dengan Pengusaha Pariwisata}

Konflik laten yang terjadi di Desa Canggu antara masyarakat lokal dengan Hotel Canggu Intercontinental lebih mengarah kepada isu-isu yang bersifat lokal. Saat penelitian dilakukan, isu yang terlihat dan beredar di masyarakat Desa Canggu menimbulkan berbagai anggapan akan terjadinya aksi yang mengarah kepada konflik manifest berbentuk fisik seperti kekerasan atau kerusuhan. Pelanggaran kesepakatan yang dilakukan oleh pihak Hotel Canggu Intercontinental terutama atas tuntutan jalan setapak sebagai akses yang menghubungkan Pura Batu Mejan dengan setra adat yang tidak terwujud menjadi indikator munculnya isu. Hal ini mencirikan adanya konflik laten diantara kedua belah pihak.

Kelian Banjar Canggu juga memperjelas tentang kekhawatiran masyarakat akan ketidakseimbangan alam sekala dan niskala yang belum dipahami oleh pihak investor dengan pernyataan sebagai berikut :

"Karena ini merupakan aspek sosial dan kita hidup di Bali ada yang dikhawatirkan karena di Bali ada Sekala dan Niskala. Karena ini pihak investor belum memahaminya dan kita sebagai masyarakat Bali ada kekhawatiran dengan perubahan itu". (Hasil wawancara dengan I Wayan Mustara, 23 Maret 2016).

Alam sekala merupakan sesuatu yang dapat dirasakan oleh panca indera sebagai sesuatu yang empiris atau nyata. Sedangkan alam niskala merupakan sesuatu yang tidak dapat dilihat namun dapat dirasakan bahwa sesuatu itu benar adanya menurut kepercayaan umat Hindu di Bali. Aspek akses menuju Pura Batu Mejan dan setra adat merupakan aspek yang sangat penting dan bila tidak dibangun dikhawatirkan akan mengganggu dan berdampak negatif pada masyarakat.

Kekhawatiran tersebut juga disampaikan kepada pemerintah Kabupaten Badung yang diwakili oleh prajuru Desa Canggu didampingi oleh Camat Kuta Utara. Mereka menyampaikan bahwa permasalahan yang terjadi di Desa Canggu tidak menemukan titik penyelesaian. Menurut kepercayaan masyarakat, jalan setapak yang dituntut tersebut merupakan hal yang sakral dimana berkaitan dengan alam niskala yang sering disebut dengan pamargi.

Selain isu mengenai kekhawatiran tentang akses jalan, Kelian Banjar Canggu juga menyatakan bahwa :

"Kedatangan investor sudah merubah wajah, dari kalangan masyarakat merasa bingung dengan penataan bangunan,yang dulunya pasir dan tidak terganggunya pandangan kita dan setelah adanya ini menjadi terganggu dan menimbulkan dampak juga" (Hasil wawancara dengan I Wayan Mustara, 23 Maret 2016).

Situasi tersebut dirasakan menimbulkan dampak yakni persaingan sosial dan ekonomi antara masyarakat lokal Desa Canggu dengan pihak Hotel Canggu Intercontinental. Masing-masing pihak merasa memiliki hak yang mutlak dan tidak boleh diganggu gugat. Pihak investor dengan hak kepemilikan lahan merasa memiliki hak penuh dan bebas membangun sesuai rencana. Sedangkan lokasi pembangunan proyek yang berada di jalan Munduk Catu Desa Canggu membuat masyarakat juga memiliki hak untuk ikut serta atas pengambilan keputusan terkait penataan wilayah. Kedua hal tersebut memunculkan kesenjangan pada aspek sosial dan ekonomi antara masyarakat lokal dengan 
pihak investor. Adanya keterlibatan masyarakat merupakan hal yang terkait dengan aspek sosial karena proyek hotel ini berada di wilayah Desa Adat Canggu. Terkait dengan aspek ekonomi, masyarakat belum merasakan adanya dampak ekonomi akibat keberadaan proyek Hotel Canggu Intercontinental. Proyek tersebut dianggap justru mengubah wajah lokasi di sekitar Pura Batu Mejan. Isu-isu tersebut dengan mudah menyebar di antara masyarakat dan saling pengaruh mempengaruhi satu sama lain. Konflik laten yang terakumulasi dapat berubah menjadi konflik manifest yang bersifat tindakan fisik atau material sewaktu-waktu bila pihak Hotel Canggu Intercontinental tetap melanggar kesepakatan awal yang telah disetujui dengan masyarakat lokal.

\section{b. Konflik Manifest antara Masyarakat dengan Pengusaha Pariwisata}

Konflik manifest yang terjadi di Desa Canggu antara masyarakat lokal dengan Hotel Canggu Intercontinental lebih mengarah pada bentuk konflik manifest yang bersifat material. Namun hal tersebut tidak menutup kemungkinan terjadinya konflik manifest yang berbentuk fisik seperti perang, kerusuhan, dan kekerasan.

Masyarakat Desa Canggu pernah menggelar aksi damai setelah sebelumnya melakukan aksi yang sama. Aksi damai yang kedua ini lebih mengarah ke dalam bentuk konkrit dengan membawa dua truk batu limestone kemudian digunakan untuk menutup akses jalan masuk proyek Hotel Canggu Intercontinental. Masyarakat juga memasang spanduk yang berisikan tuntutan masyarakat yang telah disepakati saat rapat bersama Banjar Adat Canggu. Aksi ini dipicu oleh tidak adanya tanggapan dari pihak investor dalam memenuhi tuntutan masyarakat tersebut. Adapun pernyataan dari Kelian Banjar Canggu terkait aksi tersebut yakni :
"Dari lima tuntutan itu satupun tidak ada tanggapan dari pihak investor. Munculnya aspirasi ini yaitu 5 poin tuntutan. Saat melihat bangunan itu sudah jadi dan waktu kita membuat 5 poin ini pihak investor datang, tapi yang datang adalah utusannya, tapi dia tidak bisa memberikan keputusan dan jawaban pada saat itu. Jadi sulit antara apa keinginan dari investor dan apa keinginan masyarakat karena belum pernah ketemu kan sulit jadinya. Jadi keinginan kita ketemu dengan investor terkait 5 poin itu". (Hasil wawancara dengan I Wayan Mustara, 23 Maret 2016).

Kelian Banjar Adat Canggu menyatakan bahwa dirinya sebagai perwakilan masyarakat Desa Canggu melakukan aksi tersebut dikarenakan adanya keinginan dari masyarakat untuk membicarakan situasi yang terjadi dengan pihak owner secara langsung. Namun dengan diwakilkannya pihak investor menimbulkan ketidakpuasan dari pihak masyarakat atas merespon aksi dan tuntutan masyarakat. Melihat hal ini, masyarakat Banjar Adat Canggu melakukan aksi unjuk rasa dengan menutup akses masuk menuju proyek Hotel Canggu Intercontinental.

Aksi masyarakat lokal dalam menutup akses menuju proyek ditanggapi oleh pihak investor dengan melayangkan somasi melalui kuasa hukum Yudistira Association. Biro Hukum Yudistira melayangkan surat peringatan ke pejabat Perbekel Desa Adat Canggu yang berisikan empat poin permintaan investor terhadap masyarakat. Salah satu permintaan tersebut yakni penutupan aset jalan menuju PT Canggu Intercontinental tidak sesuai prosedur dan tanpa pemberitahuan terlebih dahulu. Atas tindakan tersebut, perusahaan mengalami kerugian Rp 1.000.000.000,- per hari (Resume Rapat di Kantor Bupati, 28 Maret 2016). Penutupan akses menuju proyek mengakibatkan berhentinya pengerjaan proyek karena dirasakan sangat merugikan oleh pihak 
investor. Situasi ini menunjukkan bahwa terlihat konflik manifest dalam bentuk material yang dirasakan oleh pihak investor.

Alasan masyarakat dalam menuntut pihak investor bukan lain adalah karena tidak adanya tanggapan atas permasalahan yang dialami oleh masyarakat. Pengambilan lahan atau loloan yang berada di sebelah barat proyek, ketinggian LGater yang terlalu tinggi, serta tidak adanya jalan setapak sebagai akses yang menghubungkan antara Pura Batu Mejan dengan setra adat menjadi kekhawatiran masyarakat. Saat ombak pasang tentunya berpotensi menimbulkan bahaya apabila ada orang yang melintas lalu diterjang ombak dan terbentur dengan LGater. Hal ini diperkuat oleh KASITRANTIB Kecamatan Kuta Utara yang mengatakan :

"Dengan ketinggian LGater yang terlalu tinggi pada saat air pasang ada orang disana dan di bentur ini kemana orang ini lari? Ini dapat membahayakan, karena sudah ada kejadian disana untung tamu itu bawa papan surfing jadi bisa menyelamatkan diri. Kalau gak gitu pecah bisa kepala terhantam oleh ombak". (Hasil wawancara dengan I Gusti Ngurah Oka, S.H., 23 Mei 2016).

Jalan di depan LGater tersebut tidak hanya menjadi akses bagi wisatawan melainkan juga menjadi akses bagi masyarakat Desa Canggu terutama saat melaksanakan kegiatan upacara seperti pada hari raya Galungan, Kuningan, dan saat melasti. Akses ini digunakan karena pihak Hotel Canggu Intercontinental tidak mewujudkan jalan setapak menuju Pura Batu Mejan yang menjadi tuntutan masyarakat. Pihak Hotel Canggu Intercontinental juga membatasi masyarakat dengan mewajibkan pihak masyarakat untuk memberikan surat permohonan secara tertulis kepada manajemen hotel selambat-lambatnya tujuh hari sebelum menggunakan akses tersebut.
Pembatasan dalam penggunaan akses menuju Pura Batu Mejan tersebut tentu sangat merugikan pihak masyarakat lokal Desa Canggu yang menimbulkan konflik manifest berikutnya. Jalan yang menghubungkan Pura Batu Mejan dengan setra adat merupakan fasilitas adat yang utama dalam melakukan aktivitas keagamaan. Situasi ini dikhawatirkan akan memberikan dampak secara luas bagi masyarakat Desa Canggu.

\section{SIMPULAN DAN SARAN}

Konflik antara masyarakat Desa Canggu dengan pengusaha pariwisata adalah konflik manifest yaitu konflik yang nyata dan konflik laten berupa isu-isu yang bersifat lokal. Konflik manifest berwujud tindakan pemblokiran jalan menuju proyek Hotel Canggu Intercontinental oleh masyarakat lokal yang mengakibakan kerugian sejumlah Rp 1.000.000.000.- per hari yang dialami oleh pihak investor. Konflik laten yaitu adanya isu-isu negatif tentang konflik manifest yang dapat terjadi ketika Hotel Canggu Intercontinental tetap melanggar kesepakatan awal yang telah disetujui dengan masyarakat lokal.

Adapun saran yang peneliti berikan dalam menanggulangi konflik manifest dan konflik laten tersebut adalah :

1. Untuk masyarakat Desa Canggu. Masyarakat harus lebih berhati-hati dalam menyetujui suatu kesepakatan yang dilakukan secara lisan sebelum adanya kesepakatan tertulis. Kesepakatan secara lisan dapat terkesan mengada-ada sehingga sering terjadi kesalahpahaman antara satu pihak dengan pihak lainnya. Kesepakatan tertulis dapat menjadi sebuah bukti yang sangat kuat apabila terjadi masalah seperti ini sehingga sangat disarankan untuk dibuat agar permasalahan yang ada segera terselesaikan.

2. Untuk lembaga desa. Lembaga desa harus bekerja sama dengan pihak Pemerintah Daerah Kabupaten Badung dalam mengatasi konflik seperti ini agar segera ditemukan 
titik terang penyelesaian masalah. Lembaga desa memiliki kewenangan untuk turun tangan dalam penyelesaian konflik yakni dengan melakukan Focus Group Discussion (FGD) sehingga kedua belah pihak bisa mencari jalan keluar bersama-sama tanpa harus membuang energi dalam penerapan konflik manifest yang saat ini sedang terjadi.

3. Untuk Pemerintah Daerah Kabupaten Badung dan Pemerintah Kecamatan Kuta Utara. Kedua lembaga fasilitator dan regulator ini diharapkan agar mampu bersinergi dan dapat menjadi pihak mediasi dalam perselisihan yang terjadi antara masyarakat Desa Canggu dengan pengusaha pariwisata sehingga ditemukan solusi terbaik dari konflik yang terjadi tersebut. Peran kedua lembaga ini juga sangat berpengaruh dalam perkembangan pariwisata di wilayahnya sehingga menengahi permasalahan ini merupakan kewajibannya untuk menjaga stabilitas pariwisata.

\section{KEPUSTAKAAN/ DAFTAR PUSTAKA}

Anonim. Resume Rapat di Kantor Bupati. 2016. Undang-Undang Hukum Perdata Pasal 1320 tentang Kesepakatan.

Bungin, Burhan. 2007. Penelitian Kualitatif : Komunikasi, Ekonomi, Kebijakan Publik, dan Ilmu Sosial Lainnya. Jakarta : Kencana.

Dharmawan, Arya Hadi. 2006. Materi Seminar "KonflikSosial dan Resolusi Konflik: Analisis Sosio-Budaya (Dengan Fokus Perhatian Kalimantan Barat)" Seminar PERAGI Pontianak 10-11 Januari 2006.

Koentjaraningrat. 2009. Pengantar Ilmu Antropologi. Jakarta: Rineka Cipta.

Kusmayadi dan Endar Sugiarto. 2000. Metodologi Penelitian dalam Bidang Kepariwisataan. Jakarta: PT. Gramedia Pustaka.

Kusuma, Wahyu Darma. 2012. Konflik Pedagang dengan PT. Sanur Dinamika Mentari : Studi Kasus Pengelolaan Lahan Pembangunan Hotel di Pantai Mertasari Sanur. Jurnal Ilmiah Sosiologi, Vol.1, No.1.

Nazir M. 2003. Metode Penelitian. Jakarta : Ghalia Indonesia.

Permilasari, Ni Komang dan I Nyoman Sukma Arida. 2014. Bentuk Pengelolaan Pantai Batu Bolong sebagai Daya Tarik Wisata Surfing di Desa Canggu, Kecamatan Utara, Kabupaten Badung. Jurnal Destinasi Pariwisata, Vol. 2, No. 2.

Pitana, I Gde. 2016. Presentasi "Tantangan dan Antisipasi Pembangunan Bali ke Depan", Bali Update 2016.
Sugiyono. 2014. Metode Penelitian Kuantitatif, Kualitatif, dan $R \& D$. Bandung : Alfabeta.

Sumber lainnya :

http://polda-bali.com/berita-badung-dinilai-tak-jalankantri-hita-karana-akses-jalan-masuk-hci-ditutupwarga.html\#ixzz49zajMzXe 